\title{
Perbedaan Kadar Thyroid Stimulating Hormone dan Free Thyroxine pada Pasien Talasemia B-Mayor dengan Kelasi Besi Deferasirox dan Deferiprone
}

Aries Krisbiyantoro, Harsono Salimo,* Annang Giri Moelyo*

Magister Kedokteran Keluarga Program Pasca Sarjana, * Departemen Ilmu Kesehatan Anak Fakultas Kedokteran Universitas Sebelas Maret/RS dr. Moewardi Surakarta

Latar belakang. Talasemia $\beta$ Mayor merupakan kelainan herediter yang disebabkan gangguan produksi rantai globin. Transfusi rutin menyebabkan kelebihan besi yang tertimbun dalam jaringan sehingga menyebabkan kardiomiopati, gangguan liver, dan komplikasi endokrin. Tiroid merupakan kelenjar endokrin yang berperan penting bagi anak. Pengendapan besi di kelenjar tiroid dapat menyebabkan gangguan fungsi tiroid. Pemberian kelasi besi deferiprone dan deferasirox dan pengaruhnya pada kadar TSH dan FT4 perlu dievaluasi lebih lanjut.

Tujuan. Menganalisis perbedaan kadar TSH dan FT4 pada pasien anak dengan talasemia $\beta$ mayor menggunakan kelasi besi deferiprone dan deferasirox

Metode. Penelitian analitik dengan rancangan potong lintang (cross sectional) terhadap 43 pasien talasemia $\beta$ mayor anak berusia 9-18 tahun pada bulan April sampai Juni 2017. Pemilihan subjek dilakukan secara consecutive sampling. Data di analisis dengan SPSS 20 mengunakan uji t independen dan uji man whitney.

Hasil. Rerata usia pasien 12,5 $\pm 3,12$ tahun. Rerata kadar TSH kelompok deferiprone dan deferasirox adalah $3.051,78 \mathrm{IU} / \mathrm{ml}$ dan 2.351,29 IU/ml. Sedangkan rerata kadar FT4 untuk kelompok deferiprone dan deferasirox 15.424,12 mmol/l dan 15.822,75 IU/ ml. Tidak terdapat perbedaan kadar TSH dan FT4 pada kelompok yang mendapatkan deferasirox dan deferiprone berturut-turut nilai TSH ( $\mathrm{p}=0,148 ; \mathrm{p}>0,05)$ dan FT4 ( $\mathrm{p}=0,836 ; \mathrm{p}>0,05)$.

Kesimpulan. Tidak terdapat perbedaan kadar TSH dan FT4 pada pasien talasemia beta mayor yang mendapatkan kelasi deferasirox maupun deferiprone. Sari Pediatri 2017;19(4):209-13

Kata kunci: TSH, FT4, deferiprone, deferasirox

\section{The Differences of Thyroid Stimulating Hormone dan Free Thyroxin levels in Major Beta Thalassemia with Deferasirox and Deferiprone Chelation Therapy}

Aries Krisbiyantoro, Harsono Salimo,* Annang Giri Moelyo*

Background. Major $§$ Thalassemia represents a group of recessively inherited hemoglobin disorder, which is characterized by reduced synthesis of globins chains. Frequent blood transfusions can lead to iron overload. Its can induced cardiomyopathy, liver disease, and endocrine complications. The thyroid is the important glands in children. Iron overload can cause thyroid disarrangement. Deferiprone and deferasirox treatment are needed to evaluate about the effect in thyroid gland.

Objective. To know the differences in TSH and FT4 level in mayor thalassemia patient with deferiprone and deferasirox chelation therapy

Methods. This study was a cross-sectional study. It was performed in March to Juni 2017. Forty three patients, age between 9 years to 18 years old as subject to this study. This study examine the TSH and FT4 levels in deferiprone and deferasirox groups which met the inclusion and exclusion criteria. Differences in TSH and FT4 levels were compared between the two groups then analyzed with the Mann - Whitney test .

Results. The mean age of the subject was $12,5 \pm 3.12$ years old. The mean of TSH level in deferiprone and deferasirox group was $3.051,78 \mathrm{IU} / \mathrm{ml}$ and $2.351,29 \mathrm{IU} / \mathrm{ml}$ and the mean of FT4 level in deferiprone and deferasirox group was $15.424,12 \mathrm{mmol} / \mathrm{l}$ and $15.822,75 \mathrm{mmol} / \mathrm{l}$. There was no difference between TSH and FT4 level in deferiprone and deferasirox group. TSH ( $\mathrm{p}=0,148 ; \mathrm{p}>0,05)$ and FT4 ( $\mathrm{p}=0,836 ; \mathrm{p}>0,05)$.

Conclusion. There was no differences between TSH and FT4 level in patient beta thalassemia major with deferiprone and deferasirox. Sari Pediatri 2017;19(4):209-13

Keyword: TSH, FT4, deferiprone, deferasirox

Alamat korespondensi: Dr. Aries Krisbiyantoro. Departemen Ilmu Kesehatan Anak Fakultas Kedokteran Universitas Indonesia/RS Dr. Cipto Mangunkusumo, Jakarta. Email: dr.krisby.aries@gmail.com 
$\mathrm{T}$ alasemia adalah suatu penyakit keturunan yang diakibatkan oleh kegagalan pembentukan salah satu dari empat rantai asam amino yang membentuk hemoglobin sehingga hemoglobin tidak terbentuk sempurna. Berdasarkan data terakhir dari badan organisasi kesehatan dunia WHO disebutkan bahwa 4,5\% dari 250 juta penduduk dunia membawa genetik talasemia. Di antara 250 juta hampir $80-90$ juta membawa genetik talasemia Beta. Di pusat talasemia, Departemen Ilmu Kesehatan Anak, RS Dr Cipto Mangunkusumo (RSCM), jumlah pasien baru mencapai $80-100$ pasien per tahun. Jumlah pasien terdaftar sampai dengan bulan Juli 2010 di pusat thalassaemia adalah 1544 pasien, terdiri atas talasemia- $\beta 50,4 \%$, talasemia- $\alpha$ $2 \%$, dan sisanya lain-lain. ${ }^{1}$ Di Solo sampai dengan bulan Agustus 2016 di bagian hemato-onkologi, tercatat sekitar 149 pasien talasemia dan sebagian besar mendapatkan terapi kelasi besi.

Talasemia mayor memerlukan terapi transfusi darah secara rutin sera pemberian kelasi besi untuk mempertahankan kualitas hidupnya. Pasien harus mendapatkan transfusi darah seumur hidup untuk mengatasi anemia dan mempertahankan kadar target $\mathrm{HB} \geq 10 \mathrm{gr} / \mathrm{dl} .^{2}$ Transfusi berulang akan menyebabkan penimbunan zat besi dua kali lipat. ${ }^{3,4}$ Penimbunan zat besi yang tinggi dalam tubuh mengakibatkan terjadinya peningkatan zat besi yang bebas yang akan memacu timbulnya reactive oxygen spesies (ROS) bebas. Radikal superoksida ini mengoksidasi lipid membran sel dan protein begitu juga membran organel yang menyebabkan terjadinya kerusakan sel dan kematian. ${ }^{5,6}$

Proses pengendapan besi dalam tubuh terjadi pada organ penting (terutama jantung, hati, dan kelenjar endokrin) yang dapat mengakibatkan kerusakan jaringan dan disfungsi serta kegagalan organ. Kelenjar endokrin yang sering menjadi tempat terjadinya pengendapan besi adalah kelenjar tiroid. Toksisitas besi yang terjadi pada kelenjar tiroid akan mengakibatkan gangguan pada proses pertumbuhan dan perkembangan anak. ${ }^{7}$

Penyebab terjadinya disfungsi tiroid pada pasien talasemia adalah penimbunan besi pada kelenjar tiroid. Timbunan besi dari hasil tranfusi pada jaringan dapat diturunkan secara efektif dengan kelasi besi. Pemberian kelasi besi bertujuan untuk mengurangi toksisitas besi dalam jaringan, mencegah kelebihan besi pada organ, serta memindahkan besi dari membran sel darah merah. ${ }^{8,9}$ Tes yang paling sering digunakan untuk mengetahui kelebihan besi darah adalah konsentrasi ferritin serum atau plasma. Kadar ferritin serum yang meningkat mencerminkan jumlah cadangan besi pasien tersebut. Kadar ferritin meningkat atau menurun sesuai dengan peningkatan atau penurunan cadangan besi. Kadar ferritin yang tinggi dan menetap menunjukkan timbunan besi yang tinggi (kadar ferritin serum $>1000 \mu \mathrm{g} / \mathrm{L}$ ). Kadar ferritin serum dapat mencerminkan jumlah kadar cadangan besi pasien jika tidak disertai dengan infeksi akut atau hepatitis. ${ }^{10}$

Penggunaan kelasi besi memiliki tata cara dan aturan minum yang berbeda satu dengan yang lain. Jenis yang terbanyak dipakai adalah jenis deferiprone dan deferasirox yang keduanya diberikan secara per oral. Pemakaian deferasirox dianggap lebih mudah karena diberikan hanya satu kali perhari, sedangkan deferipron diberikan tiga kali perhari. Kemudahan terhadap mengonsumsi obat kelasi besi akan memengaruhi tingkat kepatuhan. Tingkat kepatuhan yang tinggi akan memberikan pengaruh terhadap efektifitas dalam pengunaan kelasi besi pada anak. Molekul deferasirox akan membentuk ikatan 2 kelator dengan 1 atom besi (2:1). Sementara molekul deferiprone akan membentuk ikatan 3 kelator dengan 1 atom besi. ${ }^{8}$ Deferasirox memiliki kemampuan mengikat besi bebas lebih besar daripada deferiprone, tetapi penelitian mengenai perbedaan pengaruh deferasirox dan deferiprone terhadap fungsi tiroid (TSH dan FT4) terbatas.

Berdasarkan hal tersebut penulis melakukan penelitian untuk mengetahui perbedaan pengaruh kelasi besi deferasirox dan deferiprone terhadap fungsi tiroid pada pasien talasemia $\beta$-mayor.

\section{Metode}

Penelitian dilakukan di Departemen/SMF Ilmu Kesehatan Anak Rumah Sakit Dr. Moewardi Surakarta pada bulan Maret-Juni 2017. Persetujuan tertulis (informed consent) diberikan orangtua atau wali setelah mendapat informasi secara lengkap dan mengerti untuk mengikut sertakan anaknya dalam penelitian. Kriteria inklusi meliputi pasien talasemia $\beta$ mayor usia $9-<18$ tahun, mendapat transfusi sel darah merah $\geq 10$ kali, atau nilai ferritin $\geq 1000 \mathrm{ng} / \mathrm{dL}$ (3 bulan terakhir), menggunakan kelasi besi deferasirox atau deferiprone lebih dari 1 tahun. Kriteria eksklusi meliputi sedang mengonsumi obat yang memengaruhi 
tiroid (levotiroxin, PTU, tyrozol), pasien sakit kritis, gizi buruk, pemakaian kelasi besi kombinasi dengan deferoksamin dan deferiprone.

Digunakan penelitian analitik dengan rancangan potong lintang. Pemilihan sampel dilakukan secara consecutive sampling pada pasien talasemia $\beta$ mayor anak yang memenuhi kriteria inklusi dan kontrol rutin di RSUD dr. Moewardi, Surakarta. Subjek yang memenuhi kriteria inklusi dicatat data dasar dari rekam medis, dilakukan anamnesis, pemeriksaan fisik, dan pengukuran status antropometri. Kadar ferritin, TSH, dan FT4 rata-rata bulan terakhir dicatat berdasarkan data rekam medik atau data laboratorium. Karakteristik subjek penelitian disajikan secara deskriptif. perbedaan kadar kadar TSH dan FT4 pada kelompok yang mendapatkan kelasi besi deferiprone dan deferasirox dianalisis menggunakan uji T independent dan Man Whitney. Secara statistik signifikan bila nilai $\mathrm{p}<0,05$. Digunakan SPSS versi 20.0 untuk analisis data.

Penelitian ini telah mendapat persetujuan dari Komite Etik Penelitian Fakultas Kedokteran Universitas Sebelas Maret/RS Dr.Moewardi, Surakarta dengan nomor: 169/III/HREC/2017.

\section{Hasil}

Penelitian melibatkan 43 subjek pasien talasemia $\beta$ mayor yang mendapat transfusi darah secara teratur di RSUD dr. Moewardi. Karakteristik subyek penelitian tertera pada Tabel 1.

Tabel 1. Karakteristik subyek penelitian

\begin{tabular}{|c|c|c|c|c|c|}
\hline \multirow{2}{*}{$\begin{array}{l}\text { Karakterstik } \\
\text { Jenis kelamin (\%) }\end{array}$} & \multicolumn{2}{|c|}{ Deferiprone $(n=22)$} & \multicolumn{2}{|c|}{ Deferasirox $(n=21)$} & \multirow{2}{*}{$\frac{p}{0,663}$} \\
\hline & & & & & \\
\hline Perempuan & 14 & $(63,6)$ & 12 & $(57,1)$ & \\
\hline Laki-laki & 8 & $(36,4)$ & 9 & $(42,9)$ & \\
\hline Usia* (tahun) & 12,89 & $\pm 3,66$ & 12,60 & $\pm 2,50$ & 0,767 \\
\hline Tinggi badan** $(\mathrm{cm})$ & 135,73 & $\pm 25,43$ & 141,71 & $\pm 10,56$ & 0,395 \\
\hline \multicolumn{6}{|l|}{ Status gizi $* * *(\%)$} \\
\hline Kurang & 9 & $(40,9)$ & 14 & $(66,7)$ & 0,091 \\
\hline Baik & 13 & $(59,1)$ & 7 & $(33,3)$ & \\
\hline Transfusi**(kantong/bulan) & 2,23 & $\pm 0,61$ & 2,24 & \pm 0.54 & 0,768 \\
\hline Lama transfusi**(tahun) & 7,95 & $\pm 3,00$ & 7,40 & \pm 2.49 & 0,469 \\
\hline Lama_kelasi**(tahun) & 3,55 & $\pm 1,41$ & 4,05 & \pm 1.29 & 0,172 \\
\hline \multicolumn{6}{|l|}{ Kepatuhan** (\%) } \\
\hline Rendah & 0 & 0,0 & 0 & 0,0 & 1.000 \\
\hline Sedang & 0 & 0,0 & 0 & 0,0 & \\
\hline Tinggi & 22 & $(100)$ & 21 & (100) & \\
\hline $\operatorname{SGPT}^{*}(\mathrm{u} / \mathrm{L})$ & 43,27 & $\pm 26,10$ & 54,81 & $\pm 26,53$ & 0,060 \\
\hline $\operatorname{SGOT}^{*}(\mathrm{u} / \mathrm{L})$ & 46,50 & $\pm 40,41$ & 49,90 & $\pm 18,35$ & 0,146 \\
\hline Ferritin * (ng/dL) & 3990,56 & $\pm 2625,14$ & 4522,05 & $\pm 2820,05$ & 0,608 \\
\hline
\end{tabular}

Keterangan: *data berdistribusi normal; uji independent sampel T test

** data berdistribusi tidak normal/ordinal; uji Mann Whitney $U$

*** data kategori skala nominal; uji chi sqaure

Tebel 2. Perbedaan kadar TSH dan FT4

\begin{tabular}{|c|c|c|c|c|c|}
\hline Variabel & \multicolumn{2}{|c|}{ Deferiprone $(\mathrm{n}=22)$} & \multicolumn{2}{|c|}{ Deferasirox $(n=21)$} & $\mathrm{p}$ \\
\hline $\mathrm{TSH}^{*}$ & 3,05 & $\pm 1,78$ & 2,35 & \pm 1.29 & 0,148 \\
\hline FT4** & 15,42 & $\pm 4,12$ & 15,82 & \pm 2.75 & 0,836 \\
\hline
\end{tabular}

Ket : *data berdistribusi normal; uji Independent Sampel T Test

** data berdistribusi tidak normal; uji Mann Whitney $U$ 


\section{Pembahasan}

Hasil penelitian menunjukkan bahwa penggunaan deferiprone dan deferasirox menghasilkan kadar TSH dan FT4 yang tidak bermakna secara statistik. Hasil penelitian sesuai dengan penelitian Unal $\mathrm{dkk}^{11}$ yang melaporkan bahwa deferasirox memiliki efektifitas yang sama dengan kelasi besi jenis lain terhadap organ jantung, tiroid, hati, pankreas, dan hipofisis. Penelitian dilakukan terhadap 37 pasien talasemia beta mayor yang mendapatkan kelasi besi dalam waktu minimal 1 tahun dengan subjek anak usia diatas 7 tahun yang mendapatkan kelasi besi baik monoterapi dengan deferasirox, deferiprone, deforoxamin maupun gabungan antara deferoxamin dan deferiprone. Dengan dosis rata-rata untuk deferasirox $30.8 \pm 6.3 \mathrm{mg} / \mathrm{kg} / \mathrm{hari}$ dan dosis rata rata deferiprone adalah $73,26 \pm 9,45 \mathrm{mg} /$ $\mathrm{kg} / \mathrm{hari}$. Semua pasien memiliki kepatuhan yang baik. Pada hasil penelitian didapatkan pengaruh deferasirox terhadap organ seperti jantung, liver, tiroid, pankreas yang dievaluasi dengan mengunakan MRI dalam 2 periode untuk mengetahui akumulasi dari besi. Interval pengamatan dalam 2 kali MRI adalah 6 bulan. Hasil penelitian menunjukkan deferasirox memiliki efektifitas yang sama dengan kelasi besi yang lain pada hormon tiroid yang dievaluasi dengan menggunakan MRI.

Ejaz $\mathrm{dkk}^{13}$ melakukan penelitian terhadap 100 pasien yang mendapatkan terapi deferasirox di atas 6 tahun dan mendapatkan hasil bahwa pasien yang mendapatkan terapi deferasirox mengalami penurunan ferritin, tetapi tidak signifikan. Penelitian lain juga melaporkan bahwa lama durasi dalam penggunaan kelasi besi berperan dalam menurunkan kadar ferritin. Pengunaan dosis kurang lebih $40 \mathrm{mg} / \mathrm{kgbb}$ akan menurunkan angka ferritin secara bermakna. Pada penelitian ini, lama penggunaan kelasi besi dan dosis yang digunakan tidak didata secara tepat sehingga memungkinkan efek terapi yang berbeda. Selain itu, dijelaskan bahwa awalan dalam menggunakan terapi kelasi besi dan kemampuan absorbsi obat tiap pasien menjadi masalah tersendiri terhadap respon yang terjadi pada pasien. ${ }^{13}$

Solanki $\mathrm{dkk}^{14}$ melakukan penelitian terhadap 50 anak yang menderita talasemia $\beta$ dengan usia 3-14 tahun. Hasil penelitian mendapatkan 32 (64\%) anak mengalami eutiroid, 17 (34\%) hipotiroid subklinis, dan $1(2 \%)$ hipotiroid dan tidak didapatkan hipotirod sekunder. Penelitian ini juga menunjukkan tidak ada hubungan yang signifikan antara kadar ferritin terhadap kadar TSH dan tidak ada hubungan yang signifikan antara kadar ferritin terhadap kadar FT4.

Sanjeeva $\mathrm{dkk}^{15}$ melakukan penelitian dengan metode randomized contol trial (RCT) terhadap 41 pasien thalasemia untuk menilai efektifitas dan keamanan deferasirox dibandingkan dengan deferiprone. Hasil penelitian selama 18 bulan menunjukkan bahwa kadar ferritin serum 3261 2613 $\mathrm{ng} / \mathrm{dL}$ turun menjadi $1586 \pm 766 \mathrm{ng} / \mathrm{dL}$ pada kelompok deferasirox. Sementara pada kelompok deferipron $4109 \pm 3153 \mathrm{ng} / \mathrm{dL}$ turun menjadi $1743 \pm 1138 \mathrm{ng} / \mathrm{dL}$. Hal tersebut menunjukkan bahwa deferasirox maupun deferiprone memiliki pengaruh yang sama baiknya.

Menurut Jaruratanasirikul dkk, ${ }^{16}$ berbagai macam penelitian yang dilakukan untuk mengevaluasi terhadap fungsi tiroid pada kasus talasemia memiliki hasil yang bervariasi. Hal tersebut dihubungkan dengan metode pemeriksaan fungsi tiroid yang berbeda meliputi konsentrasi T4 dan TSH serum, atau tes Thyrotropinreleasing hormone, perbedaan usia subjek penelitian, desain penelitian, tempat dan waktu penelitian, jumlah darah yang ditransfusi, dan dosis kelasi besi yang diberikan. Pemeriksaan TRH (Thyrotropin Releasing hormone) lebih sensitif daripada T4 dan TSH serum untuk mengevaluasi kelainan tiroid.

Pada penelitian ini pemeriksaan penunjang untuk mengetahui timbunan besi hanya menggunakan pemeriksaan ferritin sehingga pemeriksaan timbunan besi di jaringan kelenjar tiroid tidak bisa diperiksa secara tepat. Pemeriksaan MRI T2 untuk melihat timbunan besi di jaringan belum bisa dikerjakan karena keterbatasan fasilitas.

Menurut Rindang $\mathrm{dkk}^{17}$ tidak ada perbedaan antara jenis kelamin, lama terapi kelasi besi dan tranfusi, usia, jumlah tranfusi darah, pengunaan kelasi besi dan ferritin terhadap terjadinya hipotiroid pada pasien talasemia. Pasien talasemia yang mengalami hipotiroid dan mendapatkan kelasi besi juga tidak memiliki perbedaan yang nyata untuk terjadinya hipotiroid terkompesasi dan tidak terkompensasi. Pada penelitian ini tidak didapatkan perbedaan pada kadar FT4 setelah pemberian deferasirox atau deferiprone. Didapatkan perbedaan penurunan kadar TSH setelah pemberian deferasirox atau deferiprone, tetapi tidak bermakna secara statistik.

Keterbatasan penelitian ini adalah tidak terdapat kepustakaan yang menyebutkan berapa kadar ferritin serta lama waktu yang dibutuhkan untuk terjadinya disfungsi tiroid. Pada penelitian ini tidak dilakukan pemeriksaan terhadap hubungan antara kadar ferritin 
terhadap fungsi tiroid sehingga kondisi timbunan besi dalam tubuh dan pengaruhnya terhadap terjadinya hipotiroid tidak bisa digambarkan. Penelitian ini menggunakan ferritin sebagai indikator akumulasi besi di dalam tubuh. Ferritin memang tidak bisa menggambarkan kondisi timbunan besi pada tubuh. Namun begitu, kadar ferritin bisa meningkat karena dipengaruhi oleh faktor lain, di antaranya proses inflamasi, abnormalitas liver dan keganasan. Selain itu, banyak faktor yang berperan pada terjadinya kelainan endokrin pada pasien beta talasemia, perbedaan distribusi timbunan besi pada organ, dan sensitifitas berbagai organ yang bervariasi terhadap adanya timbunan zat besi yang menjadi alasan tidak adanya hubungan antara kadar tiroid dengan over load besi. Dengan demikian, pemberian kelasi besi dengan jenis deferasirox maupun diferiprone tentunya tidak akan membawa pengaruh yang signifikan pada fungsi tiroid, hal ini dikarenakan timbunan besi/ hemosiderosis yang belum terjadi pada organ tiroid.

\section{Kesimpulan}

Tidak terdapat perbedaan kadar TSH dan FT4 pada pasien talasemia beta mayor yang mendapatkan kelasi deferasirox maupun deferiprone.

\section{Daftar pustaka}

1. Permono \& Ugrasena. Talasemia. Dalam: B. Permono, Sutaryo, I Ugrasena, E Windiastuti, M Abdulsalam, penyunting. Buku ajar hematologi anak. Jakarta: Penerbit IDAI;2010.h.68-84.

2. Ugrasena IDG, Sudarmanto B, Lubis B, Windiastuti E, Reniarti L, Chozie NA, dkk.. Talasemia. Dalam: Standar Pelayanan Medis Kesehatan Anak. Edisi Pertama: Penerbit IDAI; 2004.h.83-4.

3. Priantono, D. Thalassemia. Dalam: Kapita Selekta Kedokteran edisi IV Jilid 1.Jakarta: Media Aesculapius Fakultas Kedokteran Universitas Indonesia; 2014.h.68-80.

4. Bejaoui, M, Guirat, N. Beta thalassemia major in a developing country: epidemiological, clinical and evolutionary aspects.
MJHID 2013;5:1-6.

5. Keikhaei B. Sequential defetoxamine deferasirox in treatment of major thalassemia with iron overload. IJPHO 2007;11:14-8.

6. Kehrer J. The haber-weiss reaction and mechanisms of toxicity. Toxicology 2000;149:43-50.

7. Kremastinos, DT, Tsersos, GA, Tsiapras DP, Karavolias, GK, Ladis, VA, Kattamis, CA.. Heart failure in beta thalassemia: a 5 year follow up study. Am J Med2001;111:349-54.

8. Capellini MD, Cohen A, Piga A. A phase 3 study of deferasirox (ICL670), a once daily oral iron chelator, inpatients with $\beta$-thalassemia. Blood 2006;107:3455-62.

9. Khider NA, Hussein FM. Assessment of thyroid function among transfusion dependant thalassemics in Erbil. MEJFM 2014;12:5-13.

10. Mashhadi, MA, Rezvani, AR, Naderi, M. Moghaddam, EM. The best iron chelation therapy in major thalassemia patients is combination of desferioxamine and deferipron. Int J Hematol Oncol Stem Cell Res 2011;5:19-22.

11. Unal S, Bas M, Haziroln T, Tuncer M, Cetin M, Gumruk F. The effect of deferasirox on iron in pituitary, pancreas, and thyroid Glands : An observasional Case Control Study. Blood 2014;24:88-92.

12. Najapifour F. Evaluation of endocrine disorder in patients with thalassemia Major. Int J Endocrinol Metab 2008;2:h.104-13.

13. Ejaz MS,Baloch S, Arif F. Efficacy and adverce effetc of oral chelating therapy deferasirox in multi tranfused pakistani children with $\beta$ thalassemia major. Pak J Med Sci 2015;31:621-5.

14. Solanki US, Bhargava AK. Assesment of thyroid function in multi tranfused children of thalasemia beta major with iron overload. WJPPS 2014;3:2177-83.

15. Sanjeeva GN, Nijaguna N, Matti M, Chebby PG. Efficay and safety of deferasirox when compared with deferiprone as oral chelating agent : Randomized control trial. JEMDS 2015;4: 4178-85.

16. Jaruratanasirikul S, Wongcharnchailert M, Laosombat V, Sangsupavanich P, Leetanaporn K. Thyroid function in -thalassemic children receiving hypertransfusions with suboptimal iron-chelating therapy. J Med Assoc Thai 2007;90:1798-802.

17. Rindang C, Batubara JRL, Amalia P, Sari H. Some aspects of thyroid dysfunction in thalassemia major patiet with severe irone overload. Pediatrica Indones 2011;51:66-72. 